\title{
Translation and adaptation to Brazilian Portuguese of the Lymphedema Rating Scale in Head and Neck Cancer
}

\author{
Tradução e adaptação para o português brasileiro da \\ Lymphedema Rating Scale in Head and Neck Cancer \\ Débora dos Santos Queija ${ }^{1}$, Lica Arakawa-Sugueno², Bruna Mello Chamma ${ }^{3}$, \\ Marco Aurélio Vamondes Kulcsar ${ }^{2,4}$, Rogério Aparecido Dedivitis ${ }^{2}$
}

\begin{abstract}
Objective: Translate to brazilian portuguese, culturally adapt and test the rating and classification scales of cervicofacial lymphedema of the MD Anderson Cancer Center Head and Neck Lymphedema Protocol (MDACC HNL) in patients undergoing treatment for head and neck cancer. Methods: The process followed international guidelines and translation stages by two head and neck surgeons, and back translation independently by two native Americans. The test of final version was based on the evaluation of 18 patients by one speech pathologist and one physical therapist who applied the scales in Portuguese. Results: The translation of the three scales was carried out independently and the translators reached a consensus for the final version. Minor modifications were made by translating two terms into the Assessment of the Face. Versions of back-translation were similar to each other. The instrument was successfully applied to patients independently. Conclusion: The translation and cultural adaptation of the assessment and rating scale of the cervicofacial lymphedema of the MD Anderson Cancer Center Head and Neck Lymphedema Protocol to the Brazilian Portuguese were successful.
\end{abstract}

Keywords: Lymphedema; Head and neck neoplasms; Neck dissection; Radiotherapy; Lymph nodes; Validation studies

\section{RESUMO}

Objetivo: Traduzir, para o português brasileiro, adaptar culturalmente e testar as escalas de avaliação e classificação do linfedema cérvico-facial do MD Anderson Cancer Center Head and Neck Lymphedema
Protocol (MDACC HNL) em pacientes submetidos ao tratamento para 0 câncer de cabeça e pescoço. Métodos: 0 processo seguiu as diretrizes internacionais e as etapas de tradução por dois cirurgiões de cabeça e pescoço, além de retrotradução de forma independente por dois nativos norte-americanos. 0 teste da versão final foi realizado a partir da avaliação de 18 pacientes por um fonoaudiólogo e um fisioterapeuta, por meio da aplicação das escalas em português. Resultados: A tradução das três escalas foi realizada de forma independente, e os tradutores chegaram a um consenso para a versão final. Foram feitas pequenas modificações, ao serem traduzidos dois termos em Assessment of the Face. As versões da retrotradução foram semelhantes entre si. 0 instrumento foi aplicado com sucesso nos pacientes de forma independente. Conclusão: $A$ tradução e a adaptação das escalas de avaliação e classificação do linfedema cérvico-facial do MD Anderson Cancer Center Head and Neck Lymphedema protocol para o português foram bem sucedidas.

Descritores: Linfedema; Neoplasias de cabeça e pescoço; Esvaziamento cervical; Radioterapia; Linfonodos; Estudos de validação

\section{INTRODUCTION}

The modalities of head and neck cancer treatment have the objective of control of the disease and patient survival. Both the surgical approach (with or without neck dissection) and exclusive or adjuvant radiation therapy or associated with chemotherapy aim to cure and preserve the function of the structures involved in

\footnotetext{
${ }^{1}$ Curso de Pós-Graduação em Fisiopatologia Experimental, Faculdade de Medicina, Universidade de São Paulo, São Paulo, SP, Brazil.

2 Faculdade de Medicina, Universidade de São Paulo, São Paulo, SP, Brazil.

${ }^{3}$ Universidade de Mogi das Cruzes, Mogi das Cruzes, SP, Brazil.

${ }^{4}$ Instituto do Câncer do Estado de São Paulo, São Paulo, SP, Brazil.

Corresponding author: Débora dos Santos Queija - Departamento de Cirurgia de Cabeça e Pescoço, Faculdade de Ciências Médicas, Universidade de São Paulo - Avenida Dr. Enéas de Aguiar, 255, Instituto Central, 8th floor, room 8,174 - Cerqueira César - Zip code: 05403-000 - São Paulo, SP, Brazil - Phone: (55 13) 3289-6314 - E-mail: dqueija@uol.com.br

Received on: Jan 21, 2017 - Accepted on: Apr 13, 2017

Conflict of interest: none.

DOI: 10.1590/\$1679-45082017A03995
} 
respiration, voice, swallowing, and as much as possible, to maintain the integrity of the patient's face and neck. ${ }^{(1,2)}$ Although treatment increases survival, there is a great risk of patients developing acute and/or chronic sequelae, with an important impact on quality of life. ${ }^{(3-5)}$

Some of the complications inherent to the treatment are secondary edema and lymphedema. Surgical manipulation can rupture the lymphatic structures and damage the adjacent soft tissues, leading to an increase of lymphatic fluid in the interstitial spaces. Lymphatic fluid retention activates inflammatory and immunological responses, resulting in fibrosis of soft and subcutaneous tissues, as well as in adipose deposition, which hinders lymphatic function. ${ }^{(6,7)}$ Postoperative edema can recede in a question of days, while edema caused by the rupture of lymphatic and vascular drainage can remain and take months to disappear. The toxicity of radiation also promotes damage that leads to alterations during and after treatment, compromising the blood vessels and the lymphatic channels of the face and neck, contributing to lymphedema. ${ }^{(3,8,9)}$

Lymphedema can involve external anatomical sites (soft tissues of the face and neck). As a consequence of external lymphedema, swelling can lead to reduced range of movement, pain, and discomfort in the neck. ${ }^{(2,3,5,10)}$

Despite lymphedema being recognized as a significant complication of head and neck cancer treatment, it still is underdiagnosed and undertreated. The literature suggests a prevalence that varies from 54 to $75 \% .^{(10,11)}$ In the last few years, some authors have been concerned about describing and characterizing lymphedema in this population, but the studies are not sufficiently enlightening. ${ }^{(12)}$

The medical literature indicates that the understanding of the pathological mechanisms points out that lymphedema and fibrosis occur continuously. Some patients present with swelling, while others may develop fibrosis without necessarily having a previous history of edema. However, many patients evolve with both, and fibrosis represents the final stage. ${ }^{(13,14)}$ Both events are generally associated with functional impairment and therefore, it is essential there be a tool that allows identification, evaluation, and measurement of its severity. ${ }^{(15,16)}$

Some protocols have been developed and tested throughout this decade with the purpose of characterizing secondary lymphedema, fibrosis, and its respective impact on the functional condition and on the quality of life of these patients, and as a treatment aid, but there still is no consensus. ${ }^{(6,8,10,12,13,15-26)}$

Only the MD Anderson Cancer Center (MDACC) group published and has used scales that allow measurements of cervicofacial lymphedema in head and neck cancer. ${ }^{(12,24,26)}$ The tool named MD Anderson Cancer Center Head and Neck Lymphedema (MDACC HNL) has been applied in other studies and compared to other instruments. ${ }^{(14,21)}$ The MDACC HNL Protocol includes the interview with the patient, the visual and tactile evaluation of the face, neck and shoulders region, and the functional assessment of swallowing and oral communication. The examination also combines photography, measurement with a measuring tape, and staging of the edema to characterize the general appearance and severity of the lymphedema. ${ }^{(12)}$

\section{OBJECTIVE}

Translate to brazilian portuguese, culturally adapt and test the rating and classification scales of cervicofacial lymphedema of the MD Anderson Cancer Center Head and Neck Lymphedema Protocol (MDACC HNL) in patients undergoing treatment for head and neck cancer.

\section{METHODS}

This research represents the initial phase of the clinical study project, approved by the Research Ethics Committee of the Medical School - Universidade de São Paulo, where it was carried out under number 137/14, from January to December 2016. To develop the project with the three scales, the author gave her permission to translate it. The Assessment of the Face, Neck Circumference, and the MDACC Head and Neck Lymphedema Rating Scale, are all parts of the MD Anderson Head and Neck Lymphedema Protocol.

Since these are strictly anatomy-related measurement scales, the translation was done independently by two head and neck surgeons with experience in head and neck edema and lymphedema, and proficiency in the English language, based on Nomina Anatomica. ${ }^{(27)}$ The process was based on international guidelines. ${ }^{(28,29)}$

There was, therefore, a consensus between the translators of a new version for Brazilian Portuguese and the posterior back-translation, performed independently by two native English language speakers. Next, the back-translation was compared with the original, analyzing aspects related to conceptual equivalence, semantics, and content. Later, a translation was prepared by the committee formed by the translators and back-translators.

The authors recommend that the lymphedema assessment be applied by a professional certified in lymphedema. ${ }^{(12,25)}$ The application of the final version was done independently by two healthcare professionals 
(one speech therapist and one physical therapist) certified by the Leduc method, by means of perimetry adapted for face and neck, and a visual and tactile evaluation, in order to stage the lymphedema. The patient was assessed individually by each one of the professionals who then compared the evaluations. Since they are similar measurements, the evaluators reached a consensus.

All patients were photographed, as recommended by the authors, using as background a checkered frame, with a Canon EOS T4i camera, and an $18-55 \mathrm{~mm}$ objective lens. ${ }^{(12)}$ The instruments were applied to 18 patients of the Head and Neck Service of the organization where the study was carried out.

\section{Evaluation of the facial edema or lymphedema}

For the visual evaluation, the patient's face was marked with an antiallergenic pen to bilaterally measure the facial proportions (Figure 1), using adapted perimetry (anthropometric measuring tape), as per the criteria adopted by Smith et al., which has two facial circumference measurements (diagonal and submentonian), point to point, and seven measurements that characterize the facial composite. ${ }^{(12)}$

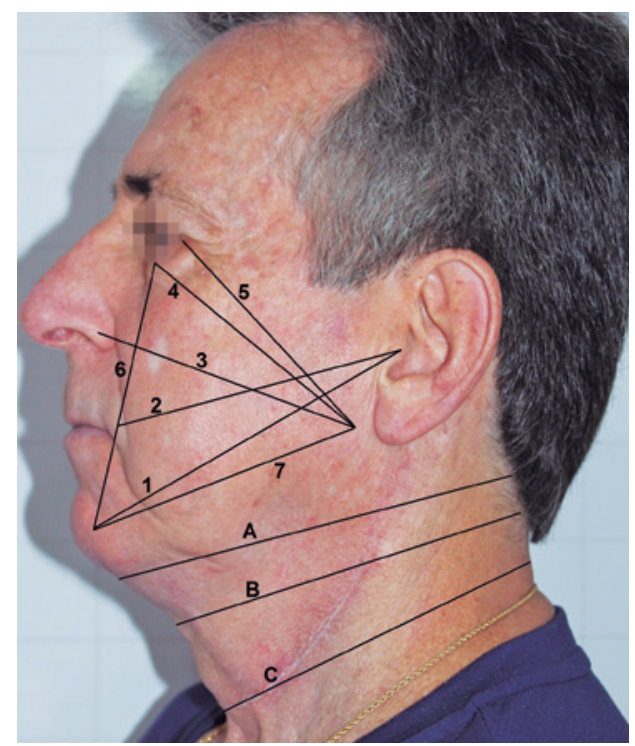

Figure 1. Measurements assessing cervicofacial edema or lymphedema

\section{Lymphedema staging}

The MD Anderson Cancer Center Head and Neck Lymphedema Rating Scale was created to characterize the presentation and severity of lymphedema in head and neck surgery, and it is based on the traditional Földi Scale for staging of lymphedema in the extremities. On the adapted MDACC scale, level 1 was divided into 1a and $1 \mathrm{~b}$ to describe the edema as pitting and non-pitting. In this case, the evaluation is made by digital pressure on the skin of the edema area, which indicates the presence of interstitial fluid in the region. Pressure was exerted softly on the evaluated area for a period of 10 seconds. The edema is considered as pitting when there is identification of the tissue depression remaining after the digital pressure. The depth of the tissue depression and the time it remains reflect the severity of the edema. Pitting edema is softer, while non-pitting edema is more rigid and does not yield to pressure. ${ }^{(12,14)}$

\section{RESULTS}

The translation of the three scales of the MDACC HNL Protocol was performed by two head and neck surgeons (Chart 1). Both translations were analyzed together by the two translators who reached a consensus for the final version.

Chart 1. Original instrument, translations, consensus, and back-translation INSTRUMENTO ORIGINAL NA LÍNGUA INGLESA

\begin{tabular}{l} 
Assessment of the face \\
(1) Facial circumference \\
(a) Diagonal: chin to crown of head \\
(b) Submental: <1cm in front of ear, vertical tape alignment \\
(2) Point to point \\
(a) Mandibular angle to mandibular angle \\
(b) Tragus to tragus \\
(c) Facial composite \\
(I) Tragus to mental protuberance \\
(II) Tragus to mouth angle \\
(III) Mandibular angle to nasal wing \\
(IV) Mandibular angle to internal eye corner \\
(V) Mandibular angle to external eye corner \\
(VI) Mental protuberance to internal eye corner \\
(VII) Mandibular angle to mental protuberance \\
Neck circumferences \\
\hline (A) Superior neck: immediately beneath mandible \\
(B) Medial neck: midway between points A and B \\
(C) Inferior neck: lowest circumferential level \\
MDACC head and neck lymphedema rating scale \\
\hline Levels \\
\hline $0 \quad$ Description \\
1a $\quad$ Soft visible edema; no pitting, reversible \\
1b Soft pitting edema; reversible \\
2 Firm pitting edema; not reversible; no tissue changes \\
Irreversible; tissue changes
\end{tabular}

Source: Smith BG, Lewin JS. Lymphedema management in head and neck cancer. Curr Opin Otolaryngol Head Neck Surg. 2010;18(3):153-8. Review. ${ }^{(12)}$ 
...Continuation

Chart 1. Original instrument, translations, consensus, and back-translation

\begin{tabular}{|c|c|}
\hline & TRADUÇÃO REALIZADA PELO TRADUTOR A \\
\hline Avaliaçã & da face \\
\hline (1) Circ & unferência facial \\
\hline (a) $D$ & agonal: mento a glabela \\
\hline (b) $\mathrm{S}$ & ibmentoniana: $<1 \mathrm{~cm}$ a frente da orelha, alinhamento vertical da fita \\
\hline (2) Pon & o a ponto \\
\hline (a) $\hat{A}$ & gulo a ângulo da mandíbula \\
\hline (b) $\operatorname{Tr}$ & águs a trágus \\
\hline (c) $\mathrm{C}$ & mposição facial \\
\hline & rágus a protuberância mentoniana \\
\hline & Trágus a comissura labial \\
\hline & Ângulo da mandíbula a asa nasal \\
\hline (IV & Ângulo da mandíbula ao canto interno do olho \\
\hline (V) & Ângulo da mandíbula ao canto externo do olho \\
\hline & Protuberância mentoniana ao canto interno do olho \\
\hline & Ângulo da mandíbula a protuberância mentoniana \\
\hline Circunfer & ências do pescoço \\
\hline (A) Part & e superior do pescoço: imediatamente abaixo da mandíbula \\
\hline (B) Part & e média do pescoço: porção média entre a superior e inferior \\
\hline (C) Part & e inferior do pescoço: nível inferior \\
\hline & Escala de linfedema em cabeça e pescoço MDACC \\
\hline Níveis & Descrição \\
\hline 0 & Sem edema visível, mas o paciente relata peso \\
\hline 1a & Edema leve visível: sem depressão, reversível \\
\hline $1 b$ & Edema com depressão leve; reversível \\
\hline 2 & Edema com depressão firme; não reversível; sem alteração dos tecidos \\
\hline 3 & Irreversível; alterações dos tecidos \\
\hline
\end{tabular}

\begin{tabular}{|c|c|}
\hline & TRADUÇÃO REALIZADA PELO TRADUTOR B \\
\hline Avaliaçã & da face \\
\hline (1) Cir & unferência da face \\
\hline (a) & iagonal: mento a glabela \\
\hline (b) & ubmentoniana: $<1 \mathrm{~cm}$ a frente da orelha, alinhamento vertical da fita \\
\hline (2) Pol & to a ponto \\
\hline (a) $\hat{A}$ & ngulo a ângulo da mandíbula \\
\hline (b) 7 & águs a trágus \\
\hline (c) $C$ & omposição facial \\
\hline & Trágus a protuberância do mento \\
\hline 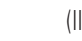 & Trágus a comissura labial \\
\hline 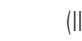 & Ângulo da mandíbula a asa nasal \\
\hline 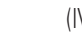 & Ângulo da mandíbula ao canto interno do olho \\
\hline 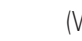 & Ângulo da mandíbula ao canto externo do olho \\
\hline (V & Protuberância do mento ao canto interno do olho \\
\hline (V & ) Ângulo da mandíbula a protuberância do mento \\
\hline Circunfe & ências do pescoço \\
\hline (A) Su & erior: imediatamente abaixo da mandíbula \\
\hline (B) $\mathrm{Me}$ & dia: porção média entre a superior e inferior \\
\hline (C) $\operatorname{lnf}$ & rior: porção mais baixa do pescoço \\
\hline & Escala de linfedema em cabeça e pescoço MDACC \\
\hline Níveis & Descrição \\
\hline 0 & Sem edema visível, mas o paciente relata peso \\
\hline 1a & Edema leve visível: sem depressão, reversível \\
\hline $1 b$ & Edema com depressão leve; reversível \\
\hline 2 & Edema com depressão firme; não reversível; sem alteração dos tecidos \\
\hline 3 & Irreversível; alterações dos tecidos \\
\hline
\end{tabular}

Fonte: Traduzida com autorizacão do autor. Smith BG, Lewin JS. Lymphedema management in head and neck cancer. Curr Opin Otolaryngol Head Neck Surg. 2010;18(3):153-8. Review. ${ }^{(12)}$
... Continuation

CONSENSO PARA A VERSÃO FINAL EM PORTUGUÊS BRASILEIRO

Avaliação da face

(1) Circunferência facial

(a) Diagonal: mento a glabela

(b) Submentoniana: $<1 \mathrm{~cm}$ a frente da orelha, alinhamento vertical da fita

(2) Ponto a ponto

(a) Ângulo a ângulo da mandíbula

(b) Trágus a trágus

(c) Composição facial

(I) Trágus a protuberância mentoniana

(II) Trágus a comissura labial

(III) Ângulo da mandíbula a asa nasal

(IV) Ângulo da mandíbula ao canto interno do olho

(V) Ângulo da mandíbula ao canto externo do olho

(VI) Protuberância mentoniana ao canto interno do olho

(VII) Ângulo da mandíbula a protuberância mentoniana

Circunferências do pescoço

(A) Superior: imediatamente abaixo da mandíbula

(B) Medial: porção média entre a superior e inferior

(C) Inferior: porção mais baixa

Escala de linfedema em cabeça e pescoço MDACC

\begin{tabular}{|ll|}
\hline Níveis & \multicolumn{1}{c|}{ Descrição } \\
\hline 0 & Sem edema visível, mas o paciente relata peso \\
$1 \mathrm{a}$ & Edema leve visível: sem depressão, reversível \\
$1 \mathrm{~b}$ & Edema com depressão leve; reversível \\
2 & Edema com depressão firme; irreversível; sem alteração dos tecidos \\
3 & Edema irreversível; alterações dos tecidos \\
\hline
\end{tabular}

\begin{tabular}{|c|c|}
\hline & $\begin{array}{l}\text { RETROTRADUÇÃO INDEPENDENTE POR DOIS NATIVOS DA } \\
\text { LÍNGUA INGLESA }\end{array}$ \\
\hline \multicolumn{2}{|c|}{ Assessment of the face } \\
\hline \multicolumn{2}{|c|}{ (1) Facial circumference } \\
\hline \multicolumn{2}{|c|}{ (a) diagonal: chin to crown of head } \\
\hline \multicolumn{2}{|r|}{ (a) submentonian: $<1 \mathrm{~cm}$ in front of ear, vertical tape alignment } \\
\hline \multicolumn{2}{|c|}{ (2) Point to Point } \\
\hline \multicolumn{2}{|c|}{ (a) Mandibular angle to mandibular angle } \\
\hline \multicolumn{2}{|c|}{ (b) Tragus to tragus } \\
\hline \multicolumn{2}{|c|}{ (c) Facial composite } \\
\hline \multicolumn{2}{|c|}{ (I) Tragus to mental protuberance } \\
\hline \multicolumn{2}{|c|}{ (II) Tragus to lip commissure } \\
\hline \multicolumn{2}{|r|}{ (III) Mandibular angle to nasal wing } \\
\hline \multicolumn{2}{|r|}{ (IV) Mandibular angle to internal eye corner } \\
\hline \multicolumn{2}{|r|}{ (V) Mandibular angle to external eye corner } \\
\hline \multicolumn{2}{|r|}{ (VI) Mandibular protuberance to internal eye corner } \\
\hline \multicolumn{2}{|r|}{ (VII) Mandibular angle to mental protuberance } \\
\hline \multicolumn{2}{|c|}{ Neck circumferences } \\
\hline \multicolumn{2}{|c|}{ (A) Superior neck: immediately beneath mandible } \\
\hline \multicolumn{2}{|c|}{ (B) Medial neck: midway between point A and C } \\
\hline \multicolumn{2}{|c|}{ (C) Inferior neck: lowest level } \\
\hline \multicolumn{2}{|r|}{ MDACC Head and neck lymphedema rating scale } \\
\hline Levels & Description \\
\hline 0 & No visible edema but patient reports heaviness \\
\hline $1 \mathrm{a}$ & Soft visible edema; no pitting, reversible \\
\hline $1 b$ & Soft pitting edema; reversible \\
\hline 2 & Firm pitting edema; irreversible; no tissue changes \\
\hline 3 & Irreversible edema; tissue changes \\
\hline
\end{tabular}


The translators made small modifications when translating two terms in the Assessment of the Face. The first was "crown of head," which when translated into Portuguese, was called "glabella." The second was "mouth angle," which was called "labial commissure." The adaptation did not compromise the content, from the semantic point of view. Additionally, the said scales should be applied by healthcare professionals with experience in anatomical terminology of the head and neck.

Based on this last version, the back-translation was done independently by two bilingual translators. The versions were similar between themselves, with no impairment of the original version.

The instrument was applied by the healthcare professionals on 18 patients at the organization where this research was carried out. Table 1 shows the characterization of cases in which the translated scales were applied. The study subjects had lesions in various sites, and the treatment used varied from surgery to radiation therapy and chemotherapy, and 15 underwent neck dissection.

Table 1. Demographic, clinical, and treatment characteristics

\begin{tabular}{|c|c|}
\hline Variable & $\mathbf{n}$ \\
\hline \multicolumn{2}{|l|}{ Age (years) } \\
\hline Minimum-maximum & $36-82$ \\
\hline Median & 60 \\
\hline Mean \pm standard deviation & $61.22 \pm 11.39$ \\
\hline \multicolumn{2}{|l|}{ Sex } \\
\hline Female & 6 \\
\hline Male & 12 \\
\hline \multicolumn{2}{|l|}{ Tumor location } \\
\hline Mouth & 7 \\
\hline Oropharynx & 5 \\
\hline Larynx & 1 \\
\hline Infraglottic cavity & 1 \\
\hline Thyroid & 1 \\
\hline Face & 2 \\
\hline Occult primary tumor & 1 \\
\hline \multicolumn{2}{|l|}{ Staging } \\
\hline Tx & 1 \\
\hline $\mathrm{T} 1 \mathrm{~b}$ & 1 \\
\hline $\mathrm{T} 2$ & 10 \\
\hline T3 & 2 \\
\hline T4 & 2 \\
\hline NO & 10 \\
\hline $\mathrm{N} 1$ & 2 \\
\hline N2 & 1 \\
\hline $\mathrm{N} 2 \mathrm{a}$ & 2 \\
\hline
\end{tabular}

... Continuation

Table 1. Demographic, clinical, and treatment characteristics

\begin{tabular}{|c|c|}
\hline Variable & $\mathbf{n}$ \\
\hline $\mathrm{N} 2 \mathrm{~b}$ & 1 \\
\hline \multicolumn{2}{|l|}{ Treatment } \\
\hline Surgery & 8 \\
\hline Surgery + radiation therapy & 4 \\
\hline Surgery + radiation therapy and chemotherapy & 5 \\
\hline Radiation therapy and chemotherapy & 1 \\
\hline \multicolumn{2}{|l|}{ Neck dissection } \\
\hline No & 3 \\
\hline Yes & 14 \\
\hline \multicolumn{2}{|l|}{ Type of neck dissection } \\
\hline Supraomohyoid & 9 \\
\hline Radical & 3 \\
\hline Modified radical & 1 \\
\hline Jugular & 1 \\
\hline Selective & 1 \\
\hline \multicolumn{2}{|l|}{ Radiation therapy } \\
\hline Minimum-maximum & $3,150-7,000$ \\
\hline Median & 1,575 \\
\hline Mean \pm standard deviation & $3,186 \pm 3,292.57$ \\
\hline \multicolumn{2}{|l|}{ Interval since end of treatment (months) } \\
\hline Minimum-maximum & $3-40$ \\
\hline Median & 6.5 \\
\hline Mean \pm standard deviation & $11.94 \pm 12.12$ \\
\hline \multicolumn{2}{|l|}{ Alcoholism } \\
\hline No & 18 \\
\hline Yes & - \\
\hline \multicolumn{2}{|l|}{ Smoking } \\
\hline No & 16 \\
\hline Yes & 2 \\
\hline \multicolumn{2}{|l|}{ Tracheostomy } \\
\hline No & 17 \\
\hline Yes & 1 \\
\hline \multicolumn{2}{|l|}{ Nasogastric tube } \\
\hline No & 17 \\
\hline Yes & 1 \\
\hline
\end{tabular}

In the group evaluated, facial lymphedema was identified in ten patients $(55.5 \%)$, four of them $(40 \%)$ type $1 \mathrm{a}$, six $(60 \%)$ type $1 \mathrm{~b}$. Table 2 indicates data related to facial measurements.

Table 3 shows the neck measurements. Fourteen $(77.7 \%)$ patients presented with lymphedema of the neck, six of them $(42.8 \%)$ type $1 \mathrm{~b}$ reversible, and eight $(57 \%)$ of the irreversible type. In this latter group with irreversible lymphedema, five $(62.5 \%)$ were type 2 , and three $(37.5 \%)$ were type 3. 
Table 2. Assessment of the face

\begin{tabular}{|c|c|c|c|c|c|c|c|c|c|c|c|c|c|c|c|c|c|c|}
\hline \multirow{3}{*}{ Patient } & \multirow{3}{*}{ 1a } & \multirow{3}{*}{$1 \mathrm{~b}$} & \multirow{3}{*}{$2 a$} & \multirow{3}{*}{$2 b$} & \multicolumn{14}{|c|}{ Measurements (mm) } \\
\hline & & & & & \multicolumn{2}{|c|}{ CI } & \multicolumn{2}{|c|}{ CII } & \multicolumn{2}{|c|}{ CIII } & \multicolumn{2}{|c|}{ CIV } & \multicolumn{2}{|c|}{ CV } & \multicolumn{2}{|c|}{ CVI } & \multicolumn{2}{|c|}{ CVII } \\
\hline & & & & & $\mathbf{R}$ & $\mathbf{L}$ & $\mathbf{R}$ & $\mathbf{L}$ & $\mathbf{R}$ & $\mathbf{L}$ & $\mathbf{R}$ & $\mathbf{L}$ & $\mathbf{R}$ & $\mathbf{L}$ & $\mathbf{R}$ & $\mathbf{L}$ & $\mathbf{R}$ & $\mathbf{L}$ \\
\hline 1 & 17 & 29 & 21.5 & 34 & 11 & 11.5 & 11 & 10.5 & 11.5 & 11 & 13.5 & 12.5 & 7 & 7.5 & 12 & 12.5 & 10 & 9.5 \\
\hline 2 & 13 & 26 & 24 & 27.5 & 13.5 & 14 & 9.5 & 10 & 10 & 11 & 13 & 13.5 & 9 & 9 & 10.5 & 10.5 & 12 & 12.5 \\
\hline 3 & 13.5 & 31 & 28 & 32 & 16 & 16 & 12 & 12 & 13 & 14 & 15.5 & 16 & 12 & 12 & 11.5 & 11.5 & 14 & 14 \\
\hline 4 & 13 & 28 & 22 & 29 & 16 & 15.5 & 11.5 & 11.5 & 11.5 & 12 & 12 & 12.5 & 9.5 & 9 & 10.5 & 11 & 11 & 11 \\
\hline 5 & 14 & 30 & 26.5 & 31 & 17 & 17.5 & 13 & 12.5 & 12.5 & 11 & 14.5 & 13.5 & 9.5 & 9.5 & 12 & 12 & 14 & 12.5 \\
\hline 6 & 15.5 & 28 & 20 & 30 & 16 & 15.5 & 12 & 11 & 11 & 10 & 12 & 12 & 9 & 9 & 12 & 12 & 10 & 10 \\
\hline 7 & 15 & 27 & 29 & 29 & 15.5 & 16 & 10 & 11 & 10 & 10 & 13 & 13 & 10 & 9 & 12 & 12 & 19 & 10 \\
\hline 8 & 17 & 29 & 17 & 23 & 16 & 17 & 12.5 & 12 & 12 & 12 & 14.5 & 14.5 & 11 & 11 & 14 & 14 & 11.5 & 10 \\
\hline 9 & 14.5 & 27.5 & 19.5 & 32 & 15 & 15 & 12 & 12 & 11 & 9 & 13 & 11 & 9 & 9 & 11 & 11 & 10 & 9.5 \\
\hline 10 & 12 & 23 & 18 & 30 & 16.5 & 17 & 11 & 12 & 12 & 11.5 & 12 & 13 & 10 & 10 & 11.5 & 11.5 & 12 & 13.5 \\
\hline 11 & 14 & 30 & 20 & 30 & 16.5 & 17 & 12.5 & 12 & 12 & 12 & 14 & 14.5 & 11 & 10 & 12 & 11.5 & 11.5 & 13 \\
\hline 12 & 15 & 27 & 21.5 & 28 & 14 & 14 & 11 & 11 & 10 & 10 & 12 & 12 & 10 & 10 & 11 & 11 & 9 & 9 \\
\hline 13 & 14 & 27 & 19.5 & 28 & 15 & 17 & 10 & 11 & 10 & 10 & 12 & 12 & 8.5 & 10 & 12 & 12 & 8 & 10 \\
\hline 14 & 15 & 27 & 18 & 29 & 15.5 & 14.5 & 11 & 10 & 10 & 11 & 12.5 & 12.5 & 9.5 & 9 & 11.5 & 11 & 9.5 & 11 \\
\hline 15 & 15 & 32 & 25 & 32 & 17 & 17 & 11.3 & 11.3 & 11 & 11 & 15.5 & 14 & 12 & 12 & 15 & 14 & 10 & 11.7 \\
\hline 16 & 13 & 26 & 17.5 & 28.5 & 15 & 15.5 & 11 & 11 & 9 & 9 & 12 & 12 & 10 & 10 & 12 & 12 & 9 & 9 \\
\hline 17 & 14 & 31 & 20 & 30 & 17 & 17 & 12 & 12 & 10 & 10 & 13 & 13 & 10 & 10 & 12 & 12 & 10 & 10 \\
\hline 18 & 19 & 30 & 18 & 29 & 16 & 16 & 11 & 11 & 10 & 10 & 13 & 13 & 11 & 11 & 12 & 12 & 9 & 9 \\
\hline
\end{tabular}

mm: millimeters; 1a diagonal: mentum to glabella; 1b submentonian: $<1 \mathrm{~cm}$ to the front of the ear, vertical tape alignment; 2a: angle to mandibular angle; $2 \mathrm{~b}$ : tragus to tragus; Cl: tragus to mentonian protuberance; Cll: tragus to labial commissure; $\mathrm{CIII}$ : mandibular angle to nasal wing; CIV: mandibular angle to the internal corner of the eve; $\mathrm{CV}$ : mandibular angle to the external corner of the eve; CVI: mentonian protuberance to the internal corner of the eve; $\mathrm{CVII}$ : mandibular angle to the mentonian protuberance; R: right; L: left.

Table 3. Measurements of the neck

\begin{tabular}{lccc}
\hline \multirow{2}{*}{ Patient } & \multicolumn{3}{c}{ Measurements (mm) } \\
\cline { 2 - 4 } & Superior & Medial & Inferior \\
\hline 1 & 43.5 & 41 & 40 \\
2 & 36 & 39 & 36.5 \\
3 & 40 & 40.5 & 40 \\
4 & 36 & 35 & 36 \\
5 & 41 & 39.5 & 41 \\
6 & 42.5 & 40 & 41 \\
7 & 36.5 & 35 & 36.5 \\
8 & 42 & 40 & 39 \\
9 & 43 & 40 & 43 \\
10 & 38 & 37.5 & 37.5 \\
11 & 39 & 40 & 40.5 \\
12 & 39 & 38 & 38 \\
13 & 37.5 & 35 & 35.5 \\
14 & 37 & 34 & 35 \\
15 & 46 & 46.5 & 44 \\
16 & 36 & 34 & 36 \\
17 & 40.5 & 42 & 44 \\
18 & 38.2 & 36 & 36.5 \\
\hline
\end{tabular}

\section{DISCUSSION}

The basic concern in seeking rating scales that allow assessment of lymphedema and fibrosis after treatment for head and neck cancer have shown that there are specificities and differences in each one. Some focus on the aspects related to edema per se, while others explore the characteristics of fibrosis. ${ }^{(7)}$ The Földi et al., Scale ${ }^{(13)}$ seems to capture the changes in soft tissues, from the softest and reversible edema, to the firmest one, which is not reversible. ${ }^{(14)}$ Even so, it is difficult to measure these alterations, a fact that justifies the scarce number of publications on the topic, and a consensus that the existing rating scales are inconsistent in capturing the characteristics of the external lymphedema after head and neck cancer.

In its initial phase, often the lymphedema can be difficult to detect. However, with the use of measuring techniques, it is possible to identify lymphatic congestion and increased pressure in the subcutaneous tissue. If the intervention is performed early, primarily in cases in which the damage is severe, the results can be satisfactory. ${ }^{(6,12,24)}$

These scales have already been used by some authors and had as criterion of choice previous experience demonstrated in studies with the instrument. (18-20,25) $^{-1}$ The staging and evaluation scales of cervicofacial lymphedema were standardized by the MDACC, and are a part of the evaluation protocol of head and 
neck cancer lymphedema of the organization; they are also associated with the functional evaluations of swallowing and with the patient's follow-up. ${ }^{(12)}$ The use of the anthropometric measuring tape for the adapted perimetry is mentioned because of the difficulty in establishing the reference points that allow constant and reproducible results. ${ }^{(18,19,23)}$ By the number of patients studied in the samples and by inconsistency of the points used in measuring, there still is no evidence in the method, but it is the form available for this purpose. It is recommended that a photographic registry be made of the front and profile views, with the patient sitting and the camera positioned on a tripod, always in the same location. We also suggest the attachment of a checkered frame on the wall behind the patient and the demarcation, with an appropriate pen, so that the record of the image is made always in the same position. This trick facilitates follow-up and the accompaniment and progress of the edema and lymphedema throughout treatment.

Recently, a protocol was drawn up with a few assessment measurements of lymphedema of head and neck cancer (ALOHA). The instrument consists of measurements of the perimetry of the superior and inferior circumferences of the neck, ear to ear, and of the extension of the lip to the inferior circumference of the neck (border of the lower lip to the inferior circumference of the neck). In addition to these, an instrument was used to evaluate the content of tissue fluid in the face and of the neck (Moisture MeterD) by means of a probe. The study indicated a weak reliability of the measurements extracted from the extension of the lip to the inferior circumference of the neck, while the comparison between the staging scale and the constant dielectric constant of the tissue achieved good reliability. The perimetry measurements of the tissue were useful to assess the changes in the tissue throughout time, and the Moisture MeterD was effective to diagnose lymphedema. ${ }^{(19)}$

The description, presentation of the external lymphedema, and results of complete decongestive therapy were verified by means of the measurements obtained with the rating scales and the MD Anderson Cancer Center Head and Neck Lymphedema Protocol cervicofacial lymphedema in 1,202 patients treated for head and neck cancer. The study identified a predominance of external $1 \mathrm{~b}$ lymphedema in $62 \%$ of patients, followed by $28 \%$ of type $1 \mathrm{a}$. The rating scale helped identify the changes obtained after treatment. The authors commented that the subdivision of level 1 into $1 \mathrm{a}$ and $1 \mathrm{~b}$ improved the ability to capture the visible non-pitting edema, which is common in head and neck cancer cases, and that is not commonly found in patients with lymphedema in the extremities. ${ }^{(24)}$

The results of this project pointed out the presence of external facial lymphedema in $55.5 \%$, and of the neck in $77 \%$ of the assessments, indicating similarity with the findings in literature. . $^{(6,11)}$

Despite the fact that they do not characterize diagnostic tools, when applying the MD Anderson Cancer Center Head and Neck Lymphedema Protocol evaluation and classification rating scales of cervicofacial lymphedema, it was possible to observe that the perimetry measurements offer an aid for the capture of the volume of edema and external lymphedema. ${ }^{(12)}$

For the application of the scales to be fruitful, it is advisable that the instrument by applied by speech therapists, physical therapists, and physicians who already have experience, as well as certification in the identification and management of edema and lymphedema in head and neck cancer. ${ }^{(12,25)}$

The study highlighted some limitations related to grading of the fibrosis. So far, when the involvement is greater, there are no validated instruments that can characterize the several more subtle degrees of tissue changes. Nevertheless, even so, the instrument used allowed conditions favorable to perceiving the differentiation between pitting and non-pitting lymphedema, such as in the cases found in head and neck cancer.

With the rating scales of external lymphedema, it is possible to incorporate systematic evaluation into the routine of patient progress. The information obtained by means of the MD Anderson Cancer Center Head and Neck Lymphedema Protocol rating scales for evaluation and classification of cervicofacial lymphedema can enable early detection and identification of lymphedema, besides providing support to referral to treatment, while at the same time, serving as an instrument for assessing the patient's clinical progress.

\section{CONCLUSION}

The translation of the MD Anderson Cancer Center Head and Neck Lymphedema Protocol rating scales for evaluation and classification into Portuguese was consistent with the original texts.

\section{REFERENCES}

1. Posner MR. Integrating systemic agents into multimodality treatment of locally advanced head and neck cancer. Ann Oncol. 2010;21 Suppl 7:vii246-51. Review.

2. Bentzen SM, Dörr W, Anscher MS, Denham JW, Hauer-Jensen M, Marks LB, et al. Normal tissue effects: reporting and analysis. Semin Radiat Oncol. 2003;13(3):189-202. Review. 
3. Murphy BA, Gilbert J, Ridner SH. Systemic and global toxicities of head and neck treatment. Expert Rev Anticancer Ther. 2007;7(7):1043-53. Review.

4. Ahlberg A, Nikolaidis P, Engström T, Gunnarsson K, Johansson H, Sharp L, et al. Morbidity of supraomohyoidal and modified radical neck dissection combined with radiotherapy for head and neck cancer: a prospective longitudinal study. Head Neck. 2012;34(1):66-72.

5. Tabibiazar R, Cheung L, Han J, Swanson J, Beilhack A, An A, et al. Inflammatory manifestations of experimental lymphatic insufficiency. PLoS Med. 2006;3(7): e254.

6. Deng J, Ridner SH, Dietrich MS, Wells N, Wallston KA, Sinard RJ, et al. Factors associated with external and internal lymphedema in patients with head and neck cancer. Int J Radiation Oncol Biol Phys. 2012;84(3):e319-28.

7 McGarvey AC, Osmotherly PG, Hoffman GR, Chiarelli PE. Lymphoedema following treatment for head and neck cancer: impact on patients, and beliefs of health professional. Eur J Cancer Care. 2014;23(3):317-27.

8. Deng J, Ridner SH, Wells N, Dietrich MS, Murphy BA. Development and preliminary testing of head and neck cancer related external lymphedema and fibrosis assessment criteria. Eur J Oncol Nurs. 2015;19(1):75-80.

9. Dietz A, Rudat V, Nollert J, Helbig M, Vanselow B, Weidauer H. [Chronic laryngeal edema as a late reaction to radiochemotherapy]. HNO. 1998;46(8):731-8. German.

10. Schiefke F, Akdemir M, Weber A, Akdemir D, Singer S, Frerich B. Function, postoperative morbidity, and quality of life after cervical sentinel node biopsy and after selective neck dissection. Head Neck. 2009;31(4):503-12.

11. Deng J, Ridner SH, Dietrich MS, Wells N, Wallston, KA, Sinard RJ, et al. Prevalence of secondary lymphedema in patients with head and neck cancer. J Pain Symptom Manage. 2012;43(2):244-52.

12. Smith BG, Lewin JS. Lymphedema management in head and neck cancer. Curr Opin Otolaryngol Head Neck Surg. 2010;18(3):153-8. Review.

13. Lymphostatic diseases. In: Földi M, Földi E, Strossenruther RH, Kubic S, editors. Foldi's textbook of lymphology for physicians and lymphedema therapists. 2nd edition. Munich: Urban and Fischer; 2007. p. 224-40.

14. The Lymphodema Framework. International Consensus. Best practice for the management of lymphedema [Internet]. London: MEP; 2006 [cited 2017 Apr 13]. Available from: http://www.soffed.co.uk/lymphorg/wp-content/ uploads/2016/03/Best_practice.pdf

15. Deng J, Ridner SH, Dietrich MS, Wells N, Murphy BA. Assessment of external lymphedema in patients with head and neck cancer: a comparison of four scales. Oncol Nurs Forum. 2013;40(5):501-6.
16. Tacani RE, Machado AF, Goes JC, Marx AG, Franceschini JP, Tacani PM. Physiotherapy on the complications of head and neck cancer: retrospective study. Int J Head Neck Surg. 2014;5(3):112-8.

17. Deng J, Ridner SH, Murphy BA, Dietrich MS. Preliminary development of a lymphedema symptom assessment scale for patients with head and neck cancer. Support Care Cancer. 2012;20(8):1911-8.

18. Piso DU, Eckardt A, Liebermann A, Gutenbrunner C, Schäfer P, Gehrke A. Early rehabilitation of head-neck edema after curative surgery for orofacial tumors. Am J Phys Med Rehabil. 2001;80(4):261-9.

19. Purcell A, Nixon J, Fleming J, McCann A, Porceddu S. Measuring head and neck lymphoedema: the "ALOHA" trial. Head Neck. 2016;38(1):79-84.

20. Arieiro EG, Diz AM, Tacani RE, Lima VP, Machado KS. [The effectiveness of the manual lymphatic drainage in the postoperative period of head and neck cancer]. Rev Bras Cir Cabeça Pescoço. 2007;36(1):43-6. Portuguese.

21. Deng J, Murphy BA, Dietrich MS, Wells N, Wallston KA, Sinard RJ, et al. Impact of secondary lymphedema after head and neck cancer treatment on symptoms, functional status, and quality of life. Head Neck. 2013;35(7):1026-35.

22. Tacani PM, Franceschini JP, Tacani RE, Machado AF, Montezello D, Góes JC, et al. Retrospective study of the physical therapy modalities applied in head and neck lymphedema treatment. Head Neck. 2016;38(2):301-8. Review.

23. Deng J, Ridner MS, Murphy BA. Lymphedema in patients with head neck cancer. Oncol Nurs Forum. 2011;38(1):E1-10. Review.

24. Smith BG, Hutcheson KA, Little LG, Skoracki RJ, Rosenthal DI, Lai SY, et al. Lymphedema outcomes in patients with head and neck cancer. Otolaryngol Head Neck Surg. 2015;152(2):284-91.

25. Deng J, Dietrich MS, Ridner SH, Fleischer AC, Wells N, Murphy BA. Preliminary evaluation of reliability and validity of head and neck external lymphedema and fibrosis assessment criteria. Eur J Oncol Nurs. 2016;22:63-70.

26. Smith BG, Lewin JS. Lymphedema management in head and neck cancer. Curr Opin Otolaryngol Head Neck Surg. 2010;18(3):153-8. Review.

27. Sociedade Brasileira de Anatomia. Terminologia Anatômica. São Paulo: Manole; 2001. v. 2.

28. Beaton DE, Bombardier C, Guillemin F, Ferraz MB. Guidelines for the process of cross-cultural adaptation of self-report measures. Spine (Phila Pa 1976). 2000;25(24):3186-91. Review.

29. Ferraz MB. Cross cultural adaptation of questionnaires: what is it and when should it be performed? J Rheumatol. 1997;24(11):2066-8. 